\title{
Determination of the optimum concentration of eggs and spermatozoa for the production of normal larvae in Pecten maximus (Mollusca, Lamellibranchia)
}

\author{
Ll. D. Gruffydd and A. R. Beaumont \\ N.E.R.C. Unit of Marine Invertebrate Biology, \\ Marine Science Laboratories; Menai Bridge, Anglesey, U. K.
}

\begin{abstract}
KURZFASSUNG: Bestimmung der optimalen Konzentration an Eiern und Spermatozoen für die Produktion normaler Larven bei Pecten maximus (Mollusca, Lamellibranchia). Die Kammuschel Pecten maximus (L.) erzeugt bei $15^{\circ} \mathrm{C}$ nahezu während des ganzen Jahres reife Keimzellen. Der Reifeprozeß der Geschlechtszellen kann durch Erniedrigung der Temperatur auf $7^{0}$ bis $8^{0} \mathrm{C}$ arretiert werden. Der Laichvorgang läßt sich dadurch auslösen, indem Kammmuscheln 2 Stunden lang aus dem Wasser entnommen werden. Danach, innerhalb von 2 bis 4 Stunden nach Rückführung in Meerwasser, werden die Keimzellen entleert. Die Spermatozoen, die gewöhnlich zuerst abgegeben werden, müssen entfernt werden, bevor die Eier erscheinen. Bei der Eiablage werden im allgemeinen auch einige Spermatozoen entlassen, so daß es auch zu Selbstbefruchtung kommt. Das prozentuale Verhältnis von Samen-zu Eizellen ist entscheidend für den Anteil abnorm gebildeter Larven, die aus den befruchteten Eiern hervorgehen können. Je mehr Spermatozoen den Eiern zugegeben werden, um so geringer ist der Prozentsatz der entstehenden Larven und desto höher ist der Anteil fehlgebildeter Larven. Die für die Erzeugung abnormer Larven verantwortlichen Faktoren sind nicht bekannt. Da Polyspermie nachgewiesen wurde, ist ein ursächlicher Zusammenhang zu der Verringerung der Larvenzahlen bzw. der Entstehung abnormer Larven nicht auszuschließen. Die Anzahl der Eier pro Volumeneinheit Meerwasser beeinflu\}t ebenfalls den Prozentsatz sich entwickelnder normaler Larven. Bei geringen Eizahlen entstehen nur wenige abnorm gestaltete Larven. In der Praxis lassen sich die besten Zuchtergebnisse bei einer Konzentration von 700 Eiern pro $\mathrm{cm}^{2}$ Bodenfläche erzielen, wobei eine große Zahl von Larven erzeugt wird, zugleich jedoch ein relativ hoher Prozentsatz Fehlentwicklungen in Kauf genommen werden muß.
\end{abstract}

\section{INTRODUCTION}

A factor that is of primary importance in the rearing of bivalve larvae, or indeed any larva, is that the fertilized eggs should produce a high proportion of normal, healthy larvae. It is, therefore, necessary to ensure that conditions during the fertilization and egg incubation stages are optimal for the production of normal larvae. Loosanoff \& Davis (1963), in a brief discussion on the effect of overcrowding of eggs on the types of larvae produced in Mercenaria mercenaria, state that gross overcrowding of eggs produces larvae that have not developed further than the shell gland stage. A reduction in the number of eggs used produces larvae with abnormal shells, 
and the fewer the eggs, the less pronounced is this abnormality. Further reduction of egg numbers produces normal, straight-hinged larvae. They found that the optimum number of eggs to use was about 30,000 per litre, and these were left undisturbed until the straight-hinged stage was reached; about $50 \%$ of the eggs developed into larvae. LoosanofF \& Davis (1950) have suggested that the last batches of eggs spent by a particular female produce feeble, unsatisfactory larvae. However, Davis \& Chanley (1956) have subsequently shown that the last eggs to be laid do not produce a significantly greater number of abnormal larvae than earlier eggs.

Egg density has also been shown to affect the larval yield in herring rearing experiments (BLAXTER 1956, 1962) and this phenomenon is by no means limited to bivalve eggs.

During early attempts at rearing Pecten maximus (L.) larvae it was suspected that both egg density and the amount of spermatozoa present (or added to the eggs) were related to the proportion of normal larvae in the resulting broods. The experiments described here were performed to find the optimum density of eggs and sperms that would produce the highest possible proportion of normal larvae.

\section{METHODS}

The conditioning of adult scallops Pecten maximus to produce ripe gametes was carried out by a method similar to that described by Loosanoff \& Davis (1963) and used by them on a variety of bivalves. Spawning was initiated by removing the scallop from the water and keeping it in air at the same temperature for approximately two hours. It was then replaced in a small container through which flowed sea water which had been filtered through nylon felt and passed through ultra-violet light in order to effect a degree of sterilization. In a ripe individual, spawning occurs within 2 to $4 \mathrm{~h}$ of re-immersion in water. The spermatozoa are usually liberated first and these are being continuously washed away by the flow of water through the container. When the first eggs appear, the container is emptied, thus removing all the remaining sperms and any faeces that have accumulated. The container is refilled with fresh sea water and, when sufficient eggs have been released, the scallop is removed. Invariably, many spermatozoa are released with the eggs and self fertilisation is almost impossible to prevent unless the eggs are washed immediately to remove the spermatozoa. This was not done in these experiments for reasons given later. The eggs are then counted and the ratio of sperms per eggs is ascertained. Appropriate volumes of the egg/sperm suspension were then taken immediately and poured into four cylindrical glass dishes, having a bottom area of $150 \mathrm{~cm}^{2}$, so that the dishes contained $10^{6}$, $10^{5}, 10^{4}$ and $10^{3} \mathrm{eggs}$, or, more appropriately, approximately $7,000,700,70$ and 7 eggs per $\mathrm{cm}^{2}$ respectively, since both eggs and sperms sink to the bottom fairly quickly. The volume in each dish was made up to 1 litre with fresh sea water. Thirty mg of Penicillin $\mathrm{G}(1,670 \mathrm{IU} / \mathrm{mg})$ and $50 \mathrm{mg}$ Streptomycin sulphate $(745 \mathrm{IU} / \mathrm{mg})$ was added to each of the dishes. They were kept at $14^{\circ} \mathrm{C}$ for 3-4 days at the end of which time the larvae produced were examined. In normal development the larvae reach the straighthinged stage by the end of the third day at this temperature. Twelve such experiments were performed. 


\section{RESULTS}

Table 1 shows the procedure adopted for conditioning two batches of scallops during 1968 and 1969. The scallops caught in March 1968 were brought into the laboratory approximately a month before their normal spawning period in the sea. The gonads were fairly full and were mainly at stage V in their development (MAson 1958). The later scallops, caught in November 1968, were filling after the September spawning and were mainly at stage IV.

Table 1

Conditioning history of two batches of scallops Pecten maximus in 1968/69

\begin{tabular}{|c|c|c|c|c|c|c|}
\hline $\begin{array}{l}\text { Date of } \\
\text { catch }\end{array}$ & $\begin{array}{l}\text { Left undisturb- } \\
\text { ed in labora- } \\
\text { tory tanks for } \\
\text { (days) }\end{array}$ & $\begin{array}{l}\text { Tem- } \\
\text { pe- } \\
\text { rature } \\
\left({ }^{0} \mathrm{C}\right)\end{array}$ & $\begin{array}{l}\text { Tempera- } \\
\text { ture in- } \\
\text { creased to } \\
\left({ }^{\circ} \mathrm{C}\right)\end{array}$ & $\begin{array}{c}\text { Duration of } \\
\text { temperature } \\
\text { rise } \\
\text { (days) }\end{array}$ & $\begin{array}{l}\text { Interval be- } \\
\text { tween end of } \\
\text { temperature } \\
\text { rise and first } \\
\text { spawning } \\
\text { (days) }\end{array}$ & $\begin{array}{c}\text { Total time } \\
\text { kept in } \\
\text { laboratory } \\
\text { (days) }\end{array}$ \\
\hline 24. 3. 1968 & 11 & 7 & 18 & 27 & 35 & 82 \\
\hline 24. 3.1968 & 36 & 7 & 18 & 28 & 29 & 93 \\
\hline 24. 3.1968 & 67 & 7 & 18 & 26 & 36 & 129 \\
\hline 22. 11.1968 & 8 & 8 & 18 & 17 & 40 & 65 \\
\hline 22. 11. 1968 & 8 & 8 & 15 & 12 & 52 & 72 \\
\hline 22. 11. 1968 & 8 & 7 & 12 & 9 & 57 & 74 \\
\hline 22. 11. 1968 & 154 & 7 & 14 & 10 & 14 & 178 \\
\hline
\end{tabular}

After capture, the scallops were brought into the laboratory and placed in constant temperature tanks (cf. GRUFFYDD \& BAKER 1969) at a lower temperature than that of the sea at the time, in order to arrest any tendency to spawn prematurely. When the scallops were placed in running sea water on board the research vessel, invariably some eggs and sperms were discharged but, provided the gonads were not too ripe, only a small proportion of the gonad was lost. Such spawning activity was usually arrested by lowering the temperature by about $3^{0}-4^{\circ} \mathrm{C}$. However, as this can only be done in the laboratory, early transfer to the laboratory is essential.

The scallops were kept at this low temperature for a period so that the ones dying because of damage incurred in capture, or because of the stress of this operation, could be found and removed. Conditioning was then commenced immediately or as soon as conditioned scallops were required. This involved a gradual temperature rise and enrichment of their food supply by addition of a mixture of laboratory cultured algae. These were added by drip-feeding 4-8 1 of the algal suspension per day into each tank. In comparison experiments, each tank contained approximately equal numbers of scallops and equal quantities of food were added to each tank daily.

After the temperature had reached the selected conditioning level, samples, consisting of two scallops, were taken from each tank at intervals no longer than one week apart and the spawning stimulus was applied. In the case of the first batch of scallops (March 1968) the interval between the end of the temperature rise and the time when the spawning stimulus was successful in inducing the discharge of ripe gametes, was very similar in all three tanks although they had been kept at the initial low tempera- 


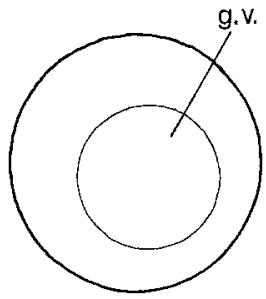

a

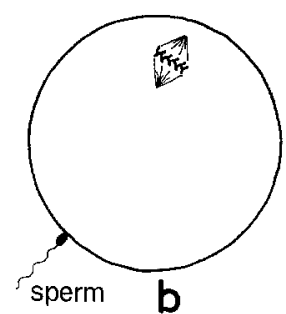

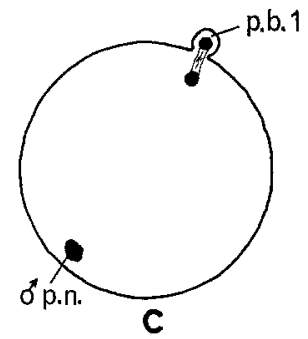
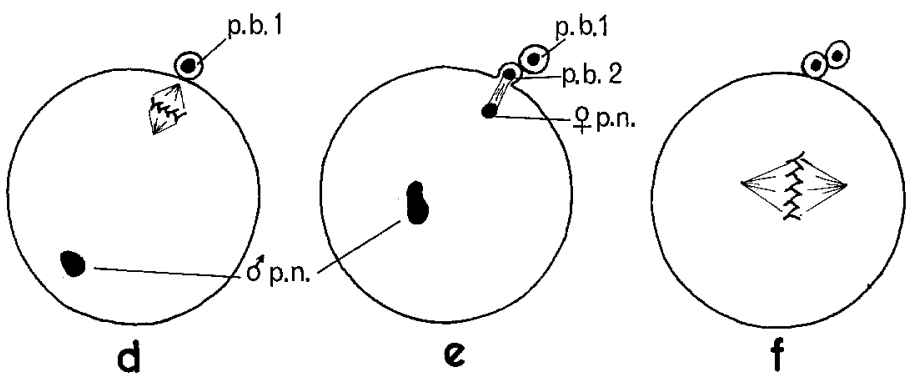

Fig. 1: Changes in the egg of Pecten maximus at fertilization. $a$ Oocyte on release; g.v. = germinal vesicle. $b$ Sperm penetration. $c, d$ and $e$ Formation of polar bodies (p.b.); male pronucleus (p.n.) migrates towards female pronucleus. $f$ First cleavage metaphase

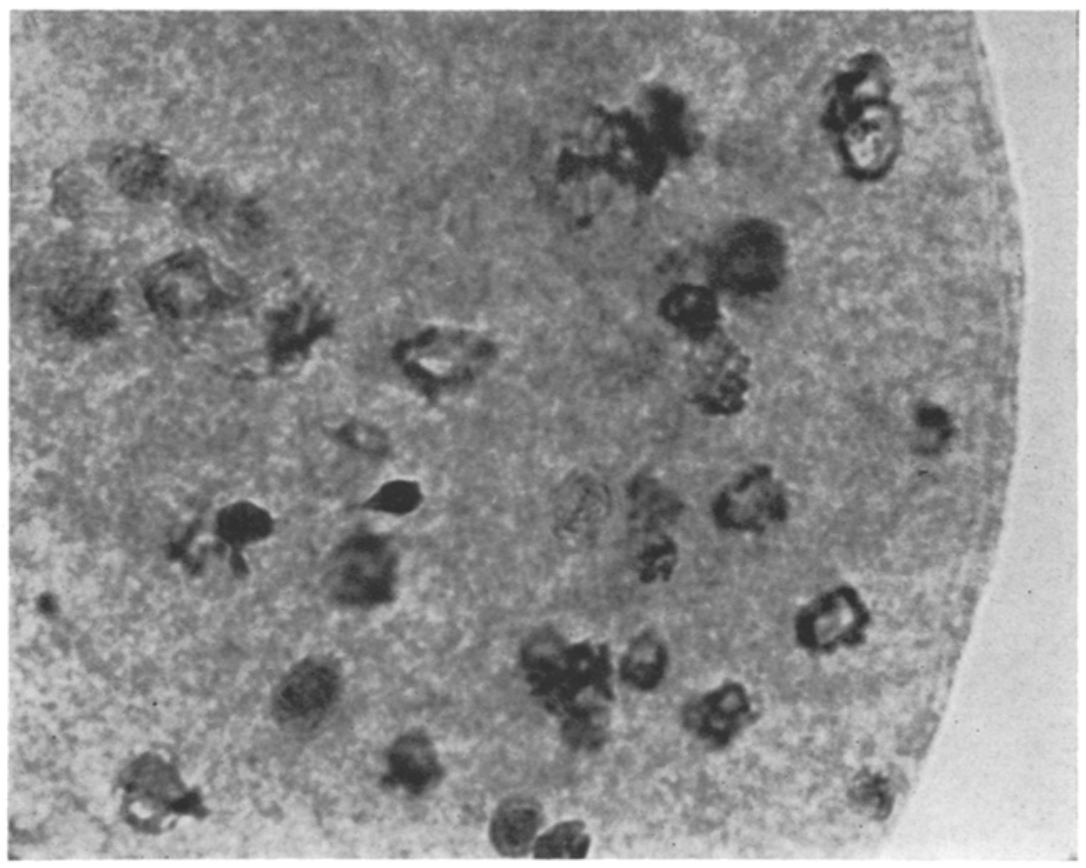

Fig. 2: Pecten maximus. Supernumerary male nuclei within one egg. (Squash preparation stained with aceto carmine) 
ture for widely different periods of time. It would seem, therefore, that in this case little or no ripening of gametes took place at this low temperature.

Occasionally, prematurely shed gametes, which tended to adhere together, were obtained as a result of the stimulus and usually not until a long time after the application of the stimulus; such releases were disregarded for the purposes of Table 1 as such eggs very rarely produced larvae.

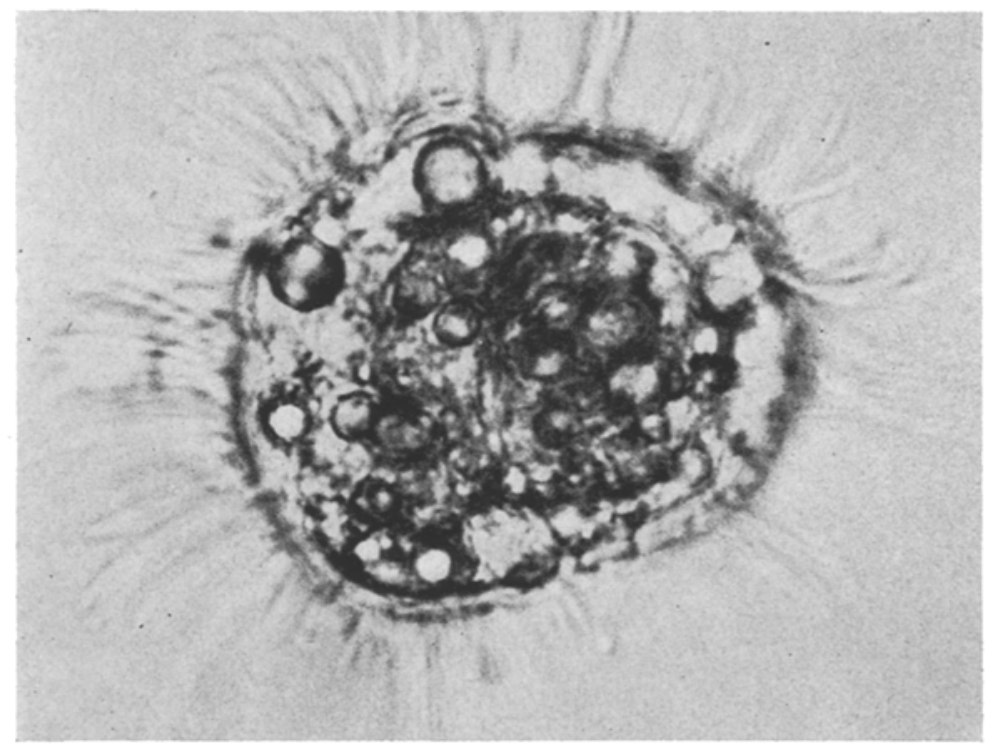

Fig. 3: Non-shelled larva of Pecten maximus

The second conditioning experiment (November 1968) was an attempt to assess the effect of temperature on the length of the conditioning period. There exists a slight tendency for this to shorten with increase in temperature. The fourth tank in this series was kept at a low temperature for 154 days and then subjected to a conditioning temperature of $14^{\circ} \mathrm{C}$. These scallops spawned within a relatively short period of time suggesting that, in this case, the gametes had matured slowly at the low temperature. This experiment suggests a method similar to that developed by Loosanofr \& Davis (1951) for delaying gonad development, thus enabling the scallops to be stored in the laboratory for use at a much later date and at a time when the gonads of natural populations were unsuitable for use. Conditioned scallops can also be kept at readiness for spawning at the final, conditioning temperature for some weeks without obvious deterioration, provided they are not disturbed and that the temperature is kept very constant. Disturbances or temperature fluctuations are likely to result in mass spawning in the tank.

During conditioning the gonad shows little signs of alteration in size and, therefore, it seems that development is limited to the completion of the maturation of eggs and sperms that had reached a certain stage of development at the time of capture. 
Scallop eggs, when released into sea water are irregular in shape but, normally, they assume a spherical shape within a few minutes. Egg batches which contained more than a small proportion of non-spherical eggs were not used in these experiments. Nonspherical eggs seem to have no attraction for sperms and their use in the experimental dishes would effectively increase the sperm/egg ratio by an unknown factor. The germinal vesicle in the spherical egg is visible and this contains chromosomes at the diakinesis stage of the first meiotic division. Development continues to the metaphase stage

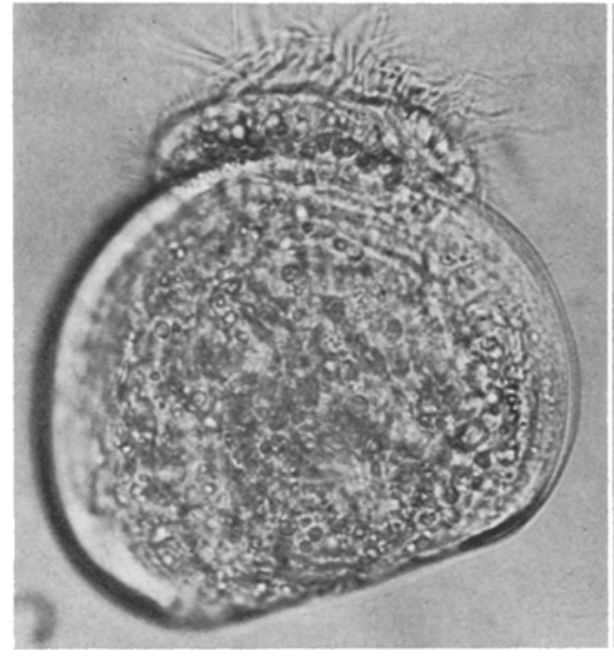

Fig. 4

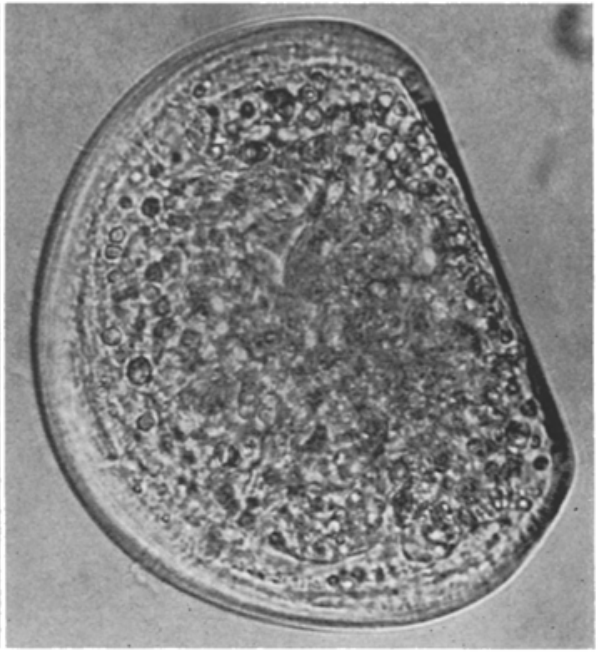

Fig. 5

Fig. 4: Pecten maximus larva with velum abnormality

Fig. 5: A normal straight-hinged larva of Pecten maximus at 4 days

with breakdown of the germinal vesicle and the egg remains at this stage until it is fertilised (Fig. 1). There is no obvious change or elevation of the egg membrane after fertilization, but now the first maturation division continues. The first polar body is usually extruded within $15 \mathrm{~min}$ of fertilization. The second maturation division quickly follows and the second polar body is extruded beneath the first. Fusion of the male and female pronuclei then proceeds.

Deviations from this normal pattern occur in dense sperm suspensions and under such conditions many sperms can enter the egg (Fig. 2). However, the fate of supernumerary sperms and that of such eggs is equally obscure.

When the larvae in each of the four experimental dishes were examined it was seen that the percentage of eggs which had developed into larvae varied considerably and that these consisted of mixtures of normal larvae and various types of abnormal larvae. The abnormal larvae could be divided into three types, the most abnormal being the one completely devoid of shell (Fig. 3). The least abnormal type of larva possessed a normal shell but the velum was mis-shapen (Fig. 4). The intermediate group consisted of larvae with abnormally shaped shells or under-developed shells (Fig. 6). Figure 5 shows an apparently normal straight-hinged larva. 


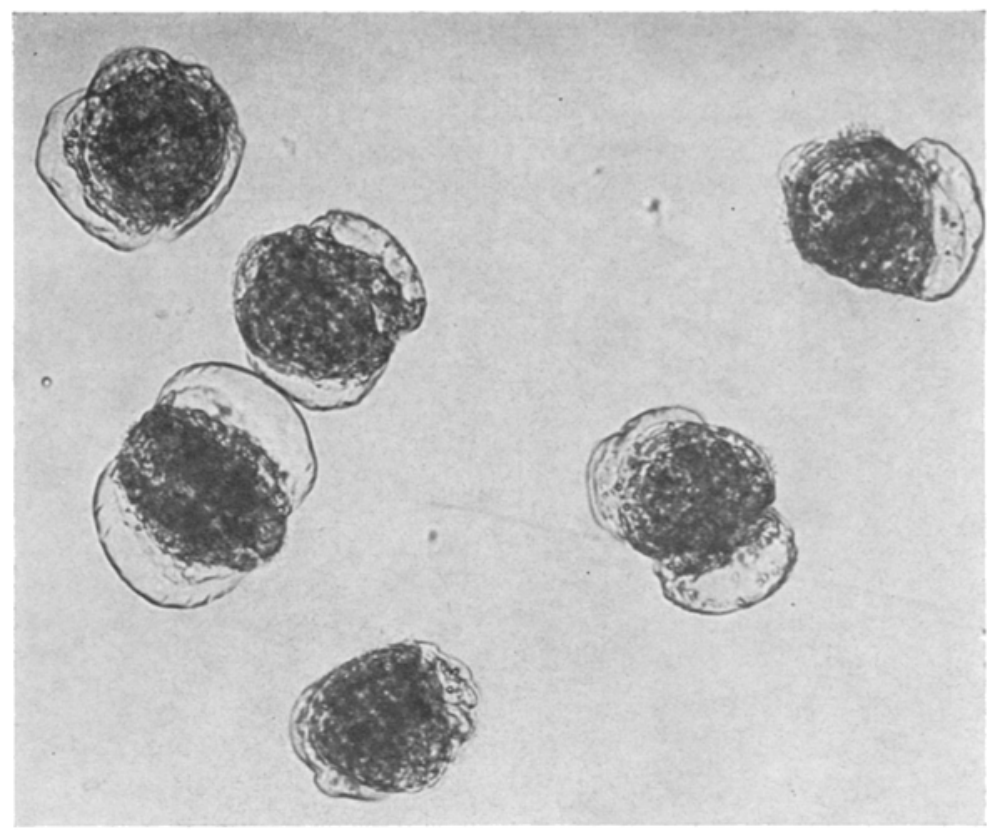

Fig. 6: Pecten maximus larvae with abnormal shells

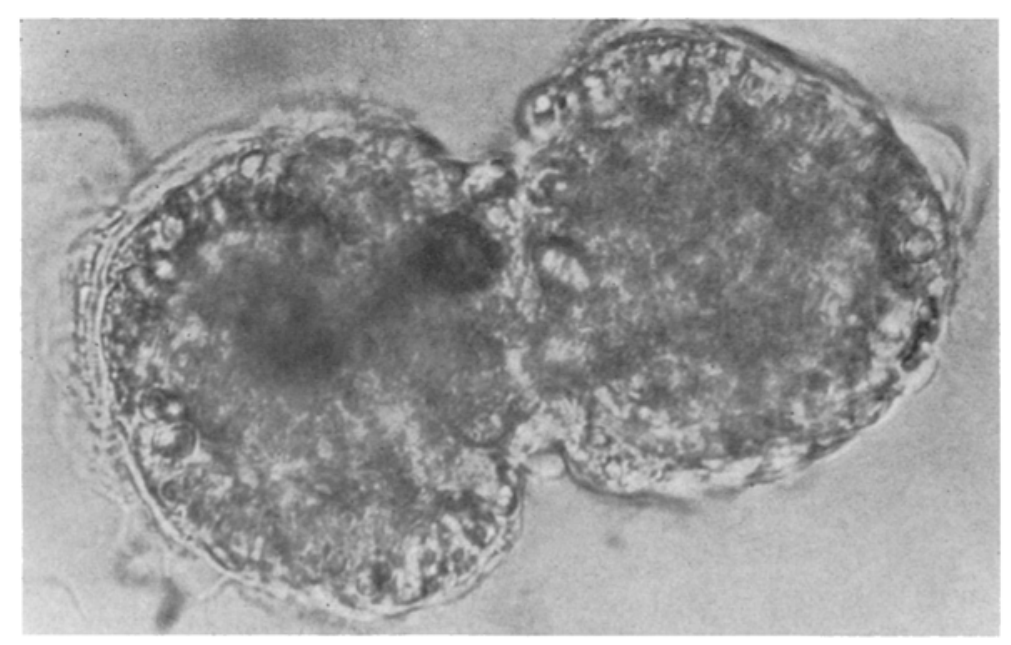

Fig. 7: Pecten maximus. The twin larva abnormality

One sample of eggs (washed on nylon mesh immediately after release to remove excess sperms) were subsequently fertilized and they produced a novel abnormality in the form of twin larvae joined along one edge (Fig. 7). Only $2 \%$ of the brood was thus affected. The fear that washing might produce added abnormalities was the main reason why this was not done in this series of experiments. 
Plotting the percentage of eggs which produced larvae in each dish, in all experiments, against the number of eggs per dish shows that the higher density of $10^{6}$ eggs per dish markedly depressed the yield of larvae as compared with the other three densities (Fig. 8). When this percentage is plotted against the number of sperms per egg for each of the four egg densities (Fig. 9), the low yield from $10^{6}$ eggs is confirmed and is hardly affected by variations in sperm concentrations. The only significant point that is displayed by the other three parts of the diagram is that high numbers of sperms per egg affect the yield adversely.

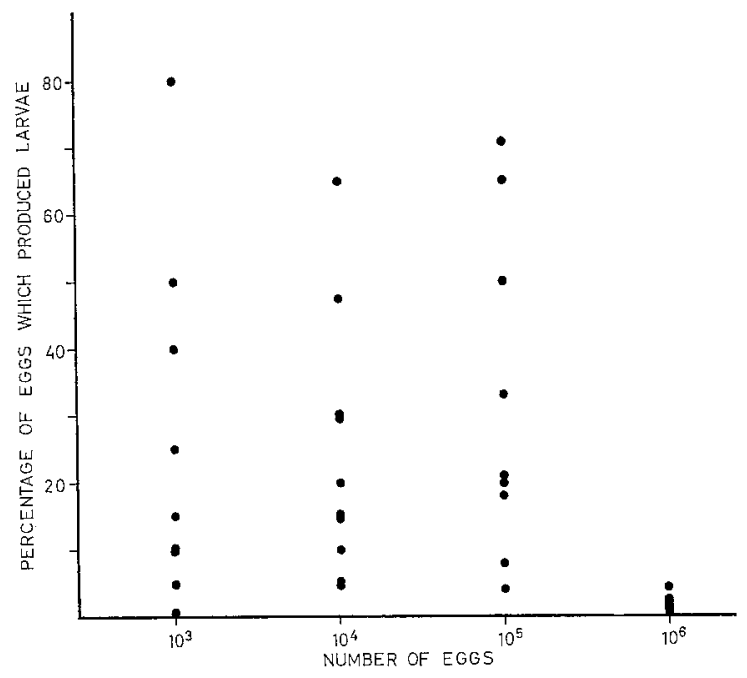

Fig. 8: Pecten maximus. A comparison of yield in terms of the percentage of eggs that produced larvae at various egg concentrations

Table 2 shows a typical experiment in this series. 'The 'No shell' abnormality is most marked at the highest egg concentration, whereas the intermediate abnormal shelled larvae were most apparent at the lesser concentrations. The velum abnormality seemed generally unrelated to egg density. The percentage of normal larvae was great-

Table 2

Percentages of Pecten maximus larvae in each category 4 days after fertilisation (4 sperms per egg; $14^{\circ} \mathrm{C}$ )

\begin{tabular}{|ccccc|}
\hline $\begin{array}{c}\text { Egg number } \\
\text { per dish }\end{array}$ & $\begin{array}{c}\text { No obvious } \\
\text { shell } \\
(\% / 0)\end{array}$ & $\begin{array}{c}\text { Abnormal } \\
\text { shell } \\
(\% / 0)\end{array}$ & $\begin{array}{c}\text { Abnormal } \\
\text { velum } \\
(\% / 0)\end{array}$ & $\begin{array}{c}\text { Normal } \\
(\% / 0)\end{array}$ \\
\hline $10^{6}$ & 100 & 0 & 0 & 0 \\
$10^{5}$ & 2 & 80 & 6 & 12 \\
$10^{4}$ & 0.5 & 75 & 5.5 & 19 \\
$10^{3}$ & 18 & 46 & 11 & 25 \\
\hline
\end{tabular}


est at the lower egg densities and vice versa. This was almost invariably the case although the actual values varied from experiment to experiment even at a given sperm concentration.

The main objective in work of this kind is, naturally, to produce as many normal larvae as possible. In order to determine the best conditions within the limits of these experiments it is necessary to examine in detail the relationship between the percent-

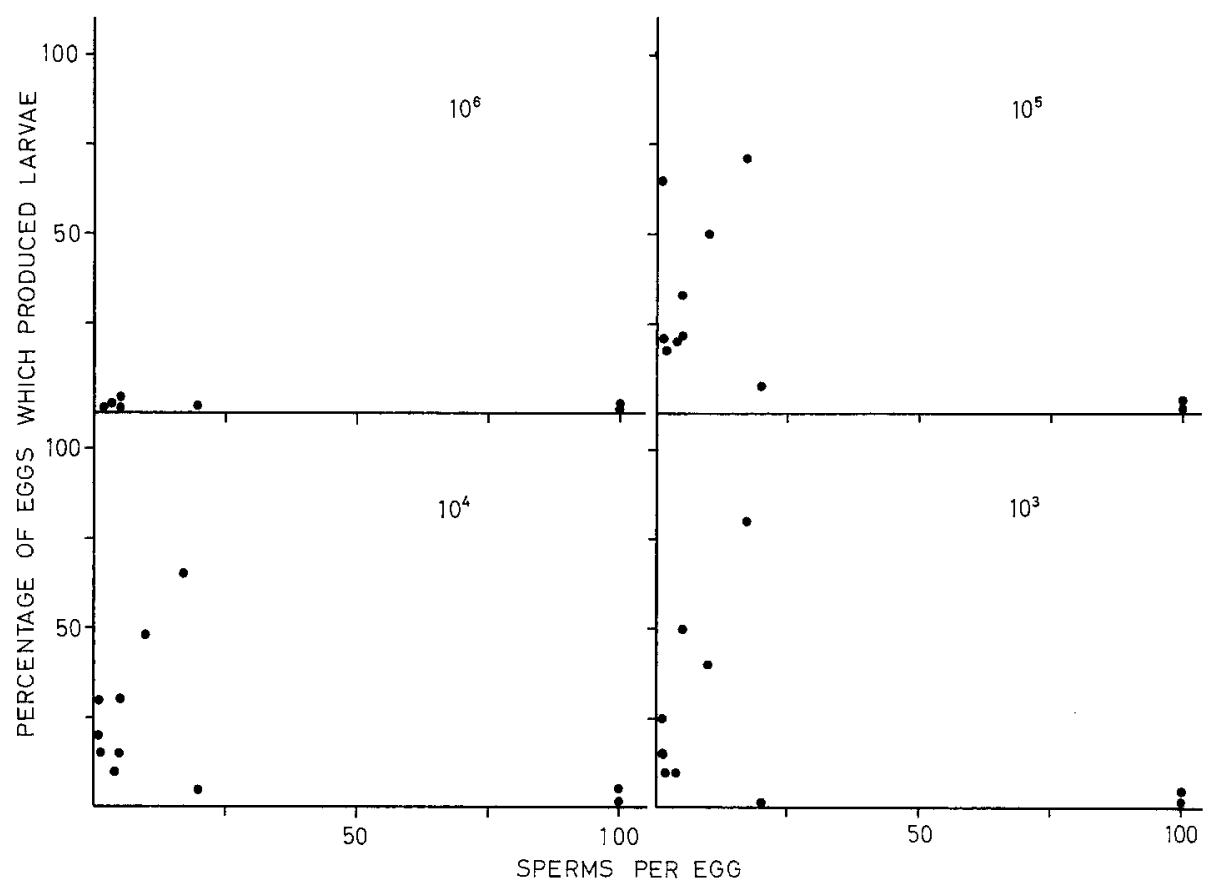

Fig. 9: Pecten maximus. Larval yield at different values of egg and sperm concentrations

age of normal larvae achieved and the egg and sperm concentrations employed. Figure 10 summarises these relationships. The results of each experiment resembled those of the next in that the percentage of normal larvae obtained decreased with increased egg density. But as the actual percentages were never coincident, visual presentation of the results in this form is difficult. To simplify presentation, the highest larval normality percentage was given the value of $100 \%$ and the remaining three values were expressed as a percentage of this best normality for each experiment. The contours in Figure 10 represent the approximate limits of selected percentages of best normality in relation to egg concentration and the number of sperms per egg. The $100 \%$ contour encloses all the best normality values from each experiment. It is evident that both high values of sperm and egg density are unfavourable for producing normal larvae but that normality at high egg densities can be improved by reducing the sperm concentration and vice versa. A multiple regression analysis performed on the original data showed that the relationship between the percentage of normal larvae and egg con- 
centration was significant $(P<0.001)$ and that the relationship between percentage normal larvae and sperm concentration was also significant $(P<0.01)$.

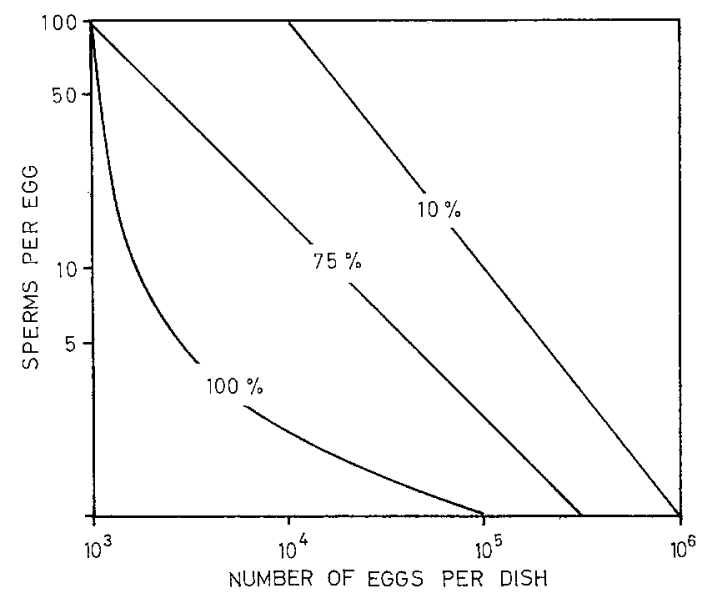

Fig. 10: Pecten maximus. Contours of percentages of best normality at different values of egg and sperm concentrations

\section{DISCUSSION}

It seems certain that, (a) the higher sperm or egg concentrations, or a combination of both, result in a low yield of larvae, and (b) that the broods produced contain a lower proportion of normal larvae than those produced by less dense concentrations of eggs and sperms.

The possibility exists that a certain degree of abnormality occurs as a result of overcrowding of the swimming larvae during the later stages of the experiments. This is unlikely, however, since the relationship between the number of larvae per dish and the percentage of these that are normal (Fig. 11) appears to be quite random and a regression analysis performed on these data showed no significance at the $5 \%$ level. The mechanisms producing the abnormalities seem, therefore, to operate at a fairly early stage in development. What these mechanisms are is unknown, but there are possible explanations. Polyspermy does occur when sperms are very numerous, but it is not known whether or not such eggs survive, and if they do, one cannot be certain that the presence of extra male nuclei would cause abnormal development. If such eggs died, then polyspermy could be a contributory cause of the low larval yield resulting from high sperm concentrations. Low yield due to high egg concentrations could be due to mortalities caused by lack of sufficient oxygen and the presence of waste products around the developing eggs, as suggested by $\operatorname{BLAXTER}(1956,1962)$ in the case of herring eggs. Large numbers of sperm, forming an envelope around the egg and eventually dying and decaying could also create similar conditions. Such decaying sperms are often found around undeveloped eggs.

TYLER (1941) maintains that when egg concentrations are high, appreciable quan- 
tities of a substance he called fertilizin, derived from the egg, is found in solution. This has the effect of agglutinating spermatozoa and destroying their capacity to fertilize. This could certainly be a factor contributing towards low yield at high egg concentrations. BLAXTER has also put forward the suggestion that mechanical interference of one egg with another can cause mortalities in dense cultures of herring eggs and, if this is the case, it is possible that abnormalities could similarly be caused in Pecten maximus.

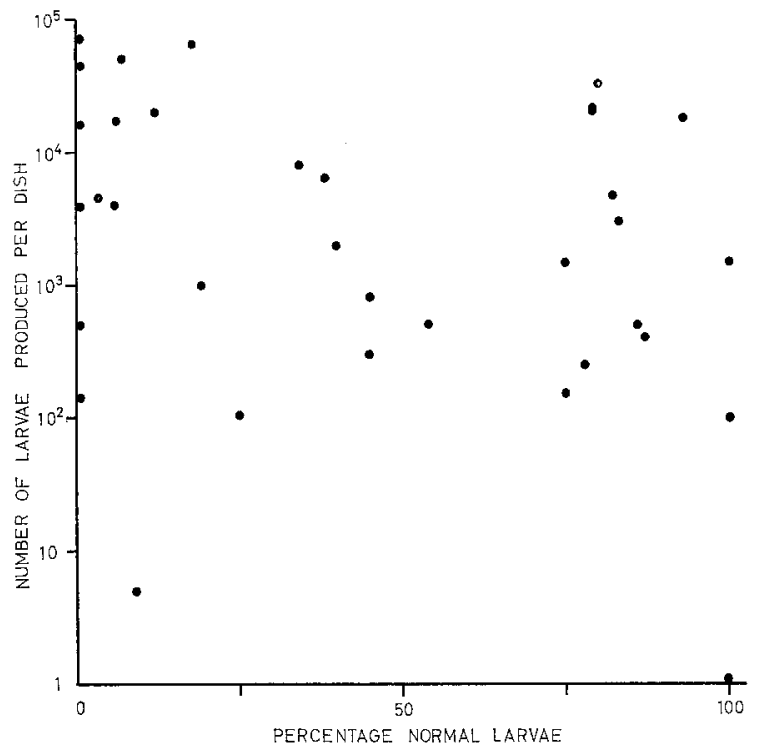

Fig. 11: Scatter diagram of the relationship between the size of broods and the normality of Pecten maximus larvae

In order to produce a high proportion of normal larvae of this scallop it is essential that the egg density is kept at around 7 eggs per $\mathrm{cm}^{2}\left(10^{3}\right.$ per dish) or less. At this density, the sperm concentration is not critical and $100 \%$ normality of the larval brood was frequently achieved. However, in order to produce large quantities of normal larvae by this method, the container would have to be unmanageably large. Therefore, one would compromise by choosing a higher egg density level which would result in a lower proportion of normal larvae being produced but where the total number would be far greater. This is illustrated in Table 3 which gives the average number of

Table 3

The average number of normal Pecten maximus larvae obtained from eggs incubated at the four concentrations, irrespective of sperm concentrations

\begin{tabular}{|lcccc|}
\hline Egg number per dish & $10^{6}$ & $10^{5}$ & $10^{4}$ & $10^{3}$ \\
\hline $\begin{array}{l}\text { Average number of } \\
\text { larvae obtained }\end{array}$ & 229 & 9,554 & 1,295 & 177 \\
\hline
\end{tabular}


normal larvae produced in the experiments described, at each of the egg densities used, disregarding sperm concentrations. $10^{5}$ eggs per dish $\left(700 \mathrm{eggs} / \mathrm{cm}^{2}\right)$ seems to be the optimum value and the figure of 9,554 normal larvae (an average based on experiments carried out at sperm concentrations ranging from 1 to 100 per egg) could be improved by using the lower sperm concentrations.

\section{SUMMARY}

1. The scallop Pecten maximus (L.) can be conditioned in the laboratory to produce ripe gametes at times other than its normal spawning seasons.

2. The spawning stimulus consists of taking the scallop out of water for a period of approximately $2 \mathrm{~h}$. Spawning occurs within 2 to $4 \mathrm{~h}$ of re-immersion in water.

3. More larvae and a higher proportion of normal larvae are produced by eggs incubated at low density levels.

4. The higher sperm concentrations produce fewer larvae and higher percentages of abnormal larvae than the lower concentrations.

5. Eggs incubated at 7 per $\mathrm{cm}^{2}$ bottom area produce very few abnormal larvae but large numbers of normal larvae can be produced more efficiently by incubating at a density level of 700 eggs per $\mathrm{cm}^{2}$ although a higher percentage of abnormal larvae must be tolerated.

Acknowledgements. Our thanks are due to Mr. B. S. SPENCER of the M.A.F.F. Laboratory at Conway for supplying inocula of Tetraselmis suecica, Isocbrysis galbana and Monocbrysis lutheri when required; to Mr. S. Buchan for advice on computer programming; to Professor D. J. CRISP, F. R. S., for advice during the preparation of this report and to Mr. J. R. PRATT and the officers and crew of the R.V. "Prince Madog" for their assistance in maintaining the stocks in good condition.

\section{LITERATURE CITED}

BLAXTER, J. H. S., 1956. Herring rearing. II. The effect of temperature and other factors on development. Mar. Res. 1956 (5), 1-19.

- 1962. Herring rearing. IV. Rearing beyond the yolk sac stage. Mar. Res. 1962 (1), 1-18.

Davis, H. C. \& Chanley, P. E., 1956. Effects of some dissolved substances on bivalve larvae. Proc. natn. Shellfish Ass. 46, 59-74.

GRUFFYDD, LL. D. \& BAKER, W. F., 1969. An integrated multiple unit controlled temperature system for sea water aquaria. Lab. Pract. 18 (3), 300-304.

Loosanofr, V.L. \& Davis, H.C., 1950. Conditioning Venus mercenaria for spawning in winter and breeding its larvae in the laboratory. Biol. Bull. mar. biol. Lab., Woods Hole 98, 60-65.

- - 1951. Delaying of spawning of lamellibranchs by low temperature. J. mar. Res. 10, 197-202.

Mason, J., 1958. The breeding of the scallop, Pecten maximus L. in Manx waters. J. mar. biol. Ass. U.K. 37 (3), 653-671.

TYLER, A., 1941. The role of Fertilizin in the fertilization of eggs of the sea urchin and other animals. Biol. Bull. mar. biol. Lab., Woods Hole 81, 190-204.

First author's address: LL. D. GRUFFYDD

Marine Science Laboratories

Menai Bridge

Anglesey, N. Wales, U.K. 